\title{
Blue mats: faunal composition and food web structure in colonial ciliate (Folliculinopsis sp.) mats at Northeast Pacific hydrothermal vents
}

\author{
Angela Kouris ${ }^{1,2, *}$, Helene Limén ${ }^{1,3}$, Catherine J. Stevens ${ }^{1,5}$, S. Kim Juniper ${ }^{1,4}$ \\ ${ }^{1}$ Centre GEOTOP, Université du Québec à Montréal, Montréal, Québec H3C 3P8, Canada \\ ${ }^{2}$ Present address: Department of Microbiology, University of Illinois at Urbana-Champaign, Urbana, Illinois 61801, USA \\ ${ }^{3}$ Present address: The Swedish Parliament, 10012 Stockholm, Sweden \\ ${ }^{4}$ Present address: School of Earth and Ocean Sciences and Department of Biology, University of Victoria, Victoria, British \\ Columbia V8W 3N5, Canada \\ ${ }^{5}$ Present address: National Institute of Water and Atmospheric Research Ltd., Wellington 6241, New Zealand
}

\begin{abstract}
The present study provides a first description of the faunal composition and food web structure associated with blue mat ciliates (Folliculinopsis sp.) at hydrothermal vents on the Juan de Fuca and Explorer Ridges in the NE Pacific. Invertebrates associated with blue mats were identified, quantified and analyzed for stable carbon and nitrogen isotopes. In addition, fatty acid analyses of blue mats were performed. We found a recurrent assemblage of invertebrates associated with the blue mats, and, in all samples, meiofauna were numerically dominant. The harpacticoid copepod Amphiascus sp. was far more abundant than any other species within the folliculinid mats. While some of the invertebrates (including Amphiascus sp.) within this assemblage seem exclusively linked to blue mats, others are known from other nearby hydrothermal vent habitats. Folliculinopsis sp. ciliates were far more depleted in $\delta^{13} \mathrm{C}$ than invertebrates within the blue mat assemblage, indicating that the latter do not feed exclusively on the former. At least 2 trophic levels exist within this assemblage, with juvenile macrofauna, ostracod and nematode species occupying higher trophic levels. The lipid profiles indi-

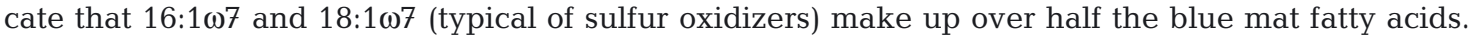
Similar to tubeworm bushes at hydrothermal vents and mussel beds at cold seeps, blue mats may create a habitat within which meiofaunal and juvenile macrobenthic species can find shelter and food, thus playing an indirect but important role in the ecology of these organisms.
\end{abstract}

KEY WORDS: Food web $\cdot$ Folliculinid $\cdot$ Hydrothermal vents $\cdot$ Stable isotopes $\cdot$ Fatty acid $\cdot$ Meiofauna Macrofauna Resale or republication not permitted without written consent of the publisher

\section{INTRODUCTION}

Hydrothermal vent habitats form on the walls of sulfide mineral edifices as well as around sites where vent fluids diffuse from cracks in the basaltic seafloor (Tunnicliffe et al. 2003). Many hydrothermal vent ecosystem studies have sought to identify and describe distinct, predictable communities related to specific hydrothermal conditions in order to understand overall hydrothermal vent ecology (Tunnicliffe et al. 1985,
Dinet et al. 1988, Tunnicliffe 1988, Van Dover 1995, Sarrazin \& Juniper 1999, Tsurumi \& Tunnicliffe 2001, Levesque et al. 2003). Species assemblages inhabiting peripheral diffuse-flow hydrothermal vent habitats have received far less attention than those found on active sulfide edifices, or in vestimentiferan tubeworm bushes and mytilid mussel beds. One peripheral assemblage, referred to here as 'blue mats', is formed by dense, blue-green sessile colonial folliculinid ciliates that individually range from 300 to $2000 \mu \mathrm{m}$ in 
length (Folliculinopsis sp.). These ciliate mats can cover extensive areas on basalt surfaces or patches on sulfide chimneys in some eastern Pacific Ocean hydrothermal vent fields and elsewhere (Tunnicliffe et al. 1985, Kouris et al. 2007). For example, in areas of widespread venting of 10 to $20 \mathrm{~m}^{2}$ or more on the Juan de Fuca Ridge, blue mats occupied as much as $70 \%$ of the basaltic substratum (Kouris et al. 2007). At some vent sites, these folliculinid ciliates have also been reported attached to mobile invertebrates (Kouris et al. 2007), as well as on the tubes of the vestimentiferan Ridgeia piscesae (Bergquist et al. 2007, Gollner et al. 2007).

To our knowledge, no other colonial ciliate has ever been reported to occupy such extensive areas in the marine environment. The ecological success of the blue mats, as evidenced by this abundance and widespread distribution around diffuse-flow vents, may be attributed to a recently proposed symbiosis involving prokaryotic symbionts hosted by these folliculinids. Abundant intra-cellular prokaryotes are apparent in transmission electron micrographs of the folliculinid cytoplasm and loricae (Kouris et al. 2007). These symbionts have also been the subject of 16S rRNA and molecular probe (CARD-FISH) studies (Kouris et al. unpubl. data).

To date, little is known about the potential importance of blue mat folliculinids to other hydrothermal vent species. Macrofaunal species are not abundant on the surface of the blue mat colonies (A. Kouris pers. obs. from video and photographic records). Densely stacked colonies of folliculinid ciliates can, however, form a substantial physical habitat within which meiofaunal and smaller macrofaunal species could find food and shelter, as has been reported for tubeworm bushes at hydrothermal vents and mussel beds at vents and cold seeps (Sarrazin \& Juniper 1999, Bergquist et al. 2003, 2007, Gollner et al. 2006, 2007, Zekely et al. 2006a,b). The role of meiofauna at hydrothermal vents has been explored in a handful of recent publications (e.g. Gollner et al. 2006, Limén \& Juniper 2006, Limén et al. 2006, 2007, 2008, Zekely et al. 2006a,b). Interactions between protozoa and meiofauna are commonly studied in other aquatic environments (e.g. Epstein \& Gallagher 1992, Hamels et al. 2001, Calbet \& Saiz 2005, Reiss \& Schmid-Araya 2008), but have yet to be explored at hydrothermal vents.

The aims of the present study were to describe the metazoan organisms living in association with the blue mats (Folliculinopsis sp.) at NE Pacific vents, to determine whether or not there was a recurrent 'blue mat fauna' and to delineate their trophic relationships. For the latter, we undertook stable carbon and nitrogen isotope analyses of organisms found in blue mat samples, and used fatty acid biomarker analysis to identify the dietary components of the blue mat ciliates.

\section{MATERIALS AND METHODS}

Sample collection. Two samples (R669 and R670) of blue mats were collected during a 2002 submersible expedition to Tubeworm vent (Magic Mountain vent field) on the Explorer Ridge in the NE Pacific. At Axial Volcano on the adjacent Juan de Fuca Ridge, samples were collected at the Village (in 2003; Sample R743) and the Marker N3 (in 2004; Sample R856) vents in the 1998 vent field (Embley et al. 1999), as well as at the Phoenix vent (in 2004; Sample R854) in the ASHES vent field. These samples were analyzed for faunal composition (Table 1), relative species abundance (Table 1 ) and stable isotope ratios (Table 2).

At Clam Bed on the Endeavour Segment of the Juan de Fuca Ridge (depth $=2190 \mathrm{~m}), 2$ samples (R682-0005 and R682-0006; approximately $1 \mathrm{~m}$ apart) were collected in 2002 for lipid analyses (Table 3) from weak diffuse-flow tubeworm habitats. The pump-operated suction sampler on the remotely operated submersible ROPOS was used for all sampling of blue mats and associated small organisms, such as juvenile macrofauna and meiofauna. For each sample, the suction sampler was operated for roughly 5 to 10 min over an area of approximately $10 \mathrm{~cm}^{2}$. Animals were retained on a double layer of $200 \mu \mathrm{m}$ Nitex mesh, fastened to the outflow of 21 suction jars. To prevent cross contamination between suction samples, the sampler hose was flushed with ambient bottom water before and after each collection. Suction samples were kept sealed during the ascent to the surface.

Faunal composition. Bulk samples for analyses of species composition and carbon and nitrogen isotopes were sorted on shipboard and frozen at $-80^{\circ} \mathrm{C}$ until needed. In the laboratory, invertebrates within the blue mat samples were separated, identified and quantified under a dissecting microscope.

Stable isotope analyses. Gut contents and shells were removed from the macrofauna, and gut content was examined under a light microscope. Prior to stable isotope analysis, all specimens were soaked in $0.1 \mathrm{~N} \mathrm{HCl}$ and MilliQ water, each in turn for $1 \mathrm{~min}$, to remove carbonates and dried at $55^{\circ} \mathrm{C}$ overnight. Samples were ground to a fine powder and distributed into tin capsules. In the case of meiofauna, individuals of the same species were pooled in tin capsules, each containing a droplet of $0.1 \mathrm{~N} \mathrm{HCl}$ (enough to cover all the animals). All specimens were dried 
Table 1. Macrofaunal and meiofaunal abundance relative to $1 \mathrm{~g}$ of blue mat (dry weight). Samples are given according to year and ROPOS dive number. Abundances were rounded to the nearest whole number. Sample N3 R856 was calculated from estimated sample dry weight

\begin{tabular}{|c|c|c|c|c|c|}
\hline \multirow{3}{*}{$\begin{array}{l}\text { Sample and site: } \\
\text { Depth }(\mathrm{m}):\end{array}$} & \multicolumn{2}{|c|}{$2002-$} & \multirow{3}{*}{$\begin{array}{c}-2003- \\
\text { R743; Village } \\
1520\end{array}$} & \multirow{3}{*}{$\begin{array}{c}\text { R856; N3 } \\
1529\end{array}$} & \multirow{3}{*}{$\begin{array}{c}004 \\
\text { R854; Phoenix } \\
1500\end{array}$} \\
\hline & R669; Tubeworm & R670; Tubeworm & & & \\
\hline & 1780 & 1780 & & & \\
\hline \multicolumn{6}{|l|}{ Macrofauna } \\
\hline Amphisamytha galapagensis & 31 & $<1$ & 55 & 333 & 71 \\
\hline Depressigyra globulus & 225 & 158 & 37 & 941 & 10 \\
\hline Lepetodrilus fucensis & $<1$ & $<1$ & $<1$ & $<1$ & 313 \\
\hline Lepetodrilus fucensis (juvenile) & 51 & 42 & 1098 & 1016 & 720 \\
\hline Unidendified polychaete & $<1$ & $<1$ & $<1$ & $<1$ & $<1$ \\
\hline Polynoidae (Polychaeta) & $<1$ & $<1$ & $<1$ & $<1$ & 20 \\
\hline Whelks & $<1$ & $<1$ & $<1$ & $<1$ & 20 \\
\hline Unidentified worm & $<1$ & $<1$ & $<1$ & $<1$ & 24 \\
\hline Pycnogonids & $<1$ & $<1$ & $<1$ & $<1$ & 27 \\
\hline \multicolumn{6}{|l|}{ Meiofauna } \\
\hline Amphiascus sp. & 2937 & 31749 & 17914 & 2749 & 8647 \\
\hline Unidentified copepods & 102 & 3161 & 27 & 201 & 125 \\
\hline Chromadoridae & 868 & 1770 & $<1$ & 1423 & 10 \\
\hline Geomonhystera sp. & 465 & 1897 & $<1$ & 5750 & 17 \\
\hline Euphilomedes climax & $<1$ & 443 & $<1$ & 6 & $<1$ \\
\hline Nereis sp. (juvenile) & $<1$ & $<1$ & 9 & $<1$ & $<1$ \\
\hline Podocopida sp. & 5 & $<1$ & 55 & 11 & 7 \\
\hline Prinospio sp. & 5 & $<1$ & $<1$ & 6 & $<1$ \\
\hline
\end{tabular}

overnight at $55^{\circ} \mathrm{C}$. Nitrogen and carbon stable isotopes were simultaneously analyzed by continuousflow isotope ratio mass spectrometry using a Carlo Erba elemental analyzer connected to a GV Instruments Isoprime isotope ratio mass spectrometer. Isotopic ratios are reported on the delta scale:

$$
\delta^{H} X=\left[\left(R_{\text {sample }} / R_{\text {standard }}\right)-1\right] \times 1000(\% \text { o })
$$

where the $H$ notation is specified for the selected element (in this study $X$ is either carbon or nitrogen). The $H$ superscript refers to the heavier stable isotope mass of the selected element (here ${ }^{13} \mathrm{C}$ or ${ }^{15} \mathrm{~N}$ ) and $R$ is the ratio of the heavy isotope to the light isotope of the selected elements (in this case, ${ }^{13} \mathrm{C} /{ }^{12} \mathrm{C}$ or ${ }^{15} \mathrm{~N} /{ }^{14} \mathrm{~N}$ ) (Fry 2006). Standards used in our analyses were Pee-Dee Belemnite (PDB) for carbon and atmospheric $\mathrm{N}_{2}$ for nitrogen.

Lipid analysis. Blue mat samples from the Clam Bed site were cleaned to remove adhering macrofauna and meiofauna and lyophilized for ca. $36 \mathrm{~h}$. Dried tissues were then placed in $2 \mathrm{ml}$ of chloroform and extracted according to Parrish (1999). Total lipids were derivatized using $\mathrm{BF}_{3}$-methanol $\left(1.5 \mathrm{~h}, 85^{\circ} \mathrm{C}\right)$ and passed through copper columns to remove sulfur (S. Wakeham unpubl. data). The resulting fatty acid methyl esters (FAME) were analyzed by flame-ionization detection on an Agilent Model $6890 \mathrm{~N}$ gas chromatograph equipped with a DB5 column (30 $\mathrm{m} \times 0.32$ $\mathrm{mm} \times 0.25 \mu \mathrm{m})$. Helium was the carrier gas, and the column was programmed as follows: $100^{\circ} \mathrm{C}$ (hold $1 \mathrm{~min}), 214^{\circ} \mathrm{C}$ at $4^{\circ} \mathrm{C} \mathrm{min}^{-1}, 216^{\circ} \mathrm{C}$ at $0.5^{\circ} \mathrm{C} \mathrm{min}^{-1}$, $219^{\circ} \mathrm{C}$ at $4^{\circ} \mathrm{C} \mathrm{min}^{-1}, 223^{\circ} \mathrm{C}$ (hold $3 \mathrm{~min}$ ) at $0.5^{\circ} \mathrm{C} \mathrm{min}^{-1}$, $270^{\circ} \mathrm{C}$ at $30^{\circ} \mathrm{C} \mathrm{min}^{-1}$ and $315^{\circ} \mathrm{C}$ (hold $10 \mathrm{~min}$ ) at $1.5^{\circ} \mathrm{C}$ $\mathrm{min}^{-1}$. FAME were identified following Ackman (1986) using the commercial standards '37-Component', 'PUFA No. 1' and 'Bacterial Acid Methyl Esters' (Supelco, Sigma-Aldrich). In the present paper, we use the term 'odd and/or branched fatty acids' (OBFA) to describe those fatty acids that have odd-numbered carbon chains and/or iso (i-) and anteiso (ai-) branches. Polyunsaturated fatty acids (PUFA) are defined as those with 3 or more double bonds. The bacterial markers summed in the feeding index 'BACT' in Table 3 are those known to be synthesized by bacteria (Stevens et al. 2008 and references therein).

\section{RESULTS}

\section{Faunal composition}

Under the light microscope, all sampled invertebrates had a blue-greenish hue. When gut contents were removed from larger, macrofaunal invertebrates (e.g. Amphisamytha galapagensis), the remaining epidermis and cuticle (as well as the removed gut contents) maintained the blue-green hue. 
Table 2. Carbon and nitrogen stable isotope ratios for faunal species associated with blue mats at sample sites from Magic Mountain vent field (Tubeworm: 2 samples) on Explorer Ridge and the 1998 vent field (Village: 1 sample; Marker N3: 1 sample) and the Ashes vent field (Phoenix: 1 sample) at Axial Volcano, on the Juan de Fuca Ridge. Number of replicate samples (n) is shown, and, for meiofauna and juvenile macrofauna, average number of pooled individuals per replicate is indicated in parentheses

\begin{tabular}{|c|c|c|c|c|c|}
\hline \multirow[t]{2}{*}{ Organism } & \multirow[t]{2}{*}{$\mathrm{n}$ (pooled) } & \multicolumn{2}{|c|}{$\delta^{13} \mathrm{C}$} & \multicolumn{2}{|c|}{$\delta^{15} \mathrm{~N}$} \\
\hline & & Mean & $\mathrm{SD}$ & Mean & $\mathrm{SD}$ \\
\hline \multicolumn{6}{|l|}{ R669 Tubeworm } \\
\hline Folliculinopsis sp. & 2 & -30.2 & 0.1 & 4.7 & 0.1 \\
\hline Amphiascus sp. & $2(163)$ & -23.3 & 0.0 & 4.3 & 0.1 \\
\hline Chromadoridae & $1(170)$ & -23.8 & & 7.4 & \\
\hline Geomonhystera sp. & $1(91)$ & -23.5 & & 4.8 & \\
\hline $\begin{array}{l}\text { Lepetodrilus fucensis } \\
\text { (juvenile) }\end{array}$ & $2(5)$ & -20.0 & 3.1 & 5.1 & 0.4 \\
\hline Depressigyra globulus & 5 & -20.8 & 3.6 & 7.0 & 0.3 \\
\hline $\begin{array}{l}\text { Amphisamytha } \\
\text { galapagensis }\end{array}$ & 1 & -28.8 & & 4.6 & \\
\hline Conical mollusk & 1 & -27.4 & & 6.3 & \\
\hline \multicolumn{6}{|l|}{ R670 Tubeworm } \\
\hline Folliculinopsis sp. & 2 & -33.1 & 0.4 & 4.6 & 0.2 \\
\hline Amphiascus sp. & $5(169)$ & -26.3 & 0.4 & 4.9 & 0.4 \\
\hline Without gravid & $4(172)$ & -26.2 & 0.1 & 4.8 & 0.1 \\
\hline Chromadoridae & $1(168)$ & -24.8 & & 6.9 & \\
\hline Euphilomedes climax & 5 & -26.3 & & 8.4 & 0.7 \\
\hline Lepetodrilus fucensis & 4 & -28.8 & 0.2 & 6.0 & 0.7 \\
\hline Depressigyra globulus & 5 & -24.0 & 1.6 & 6.8 & 0.5 \\
\hline \multicolumn{6}{|l|}{ R743 Village } \\
\hline Folliculinopsis sp. & 2 & -32.5 & 0.1 & 5.5 & 0.1 \\
\hline Amphiascus sp. & $5(180)$ & -25.4 & 0.7 & 5.0 & 0.6 \\
\hline Without gravid & 4 (199) & -25.1 & 0.5 & 4.7 & 0.3 \\
\hline $\begin{array}{l}\text { Lepetodrilus fucensis } \\
\text { (juvenile) }\end{array}$ & $4(8)$ & -22.5 & 0.7 & 4.2 & 0.5 \\
\hline $\begin{array}{l}\text { Amphisamytha } \\
\text { galapagensis }\end{array}$ & 2 & -24.0 & 0.1 & 8.2 & 0.6 \\
\hline \multicolumn{6}{|l|}{ R856 Marker N3 } \\
\hline Folliculinopsis sp. & 2 & -33.4 & 0.3 & 4.8 & 0.1 \\
\hline Amphiascus sp. & $3(144)$ & -24.2 & 0.7 & 6.1 & 0.2 \\
\hline Without gravid & $2(166)$ & -23.8 & 0.4 & 6.0 & 0.2 \\
\hline Chromadoridae & 1 (185) & & & 5.2 & \\
\hline $\begin{array}{l}\text { Lepetodrilus fucensis } \\
\text { (juvenile) }\end{array}$ & $1(7)$ & -19.2 & & 2.7 & \\
\hline Depressigyra globulus & $4(4)$ & -20.8 & 1.9 & 5.1 & 1.8 \\
\hline $\begin{array}{l}\text { Amphisamytha } \\
\text { galapagensis }\end{array}$ & 13 & -29.1 & 2.2 & 6.2 & 0.2 \\
\hline \multicolumn{6}{|l|}{ R854 Phoenix } \\
\hline Folliculinopsis sp. & 1 & -35.0 & & 6.2 & \\
\hline Amphiascus sp. & $4(181)$ & -26.4 & 0.7 & 4.7 & 0.1 \\
\hline Without gravid & $3(186)$ & -27.7 & 0.1 & 4.6 & 0.1 \\
\hline $\begin{array}{l}\text { Lepetodrilus fucensis } \\
\text { (juvenile) }\end{array}$ & $2(8)$ & -25.8 & 0.5 & 4.5 & 1.7 \\
\hline Lepetodrilus fucensis & 5 & -18.4 & 5.6 & 7.5 & 0.9 \\
\hline Depressigyra globulus & 2 & -20.7 & 0.4 & 7.0 & 0.2 \\
\hline $\begin{array}{l}\text { Amphisamytha } \\
\text { galapagensis }\end{array}$ & 18 & -25.7 & 3.5 & 4.9 & 1.5 \\
\hline Polynoidae (Polychaeta) & 5 & -17.0 & 5.7 & 7.8 & 1.4 \\
\hline Tubeworm & 5 & -16.0 & 1.5 & 5.8 & 1.9 \\
\hline Pycnogonid & 5 & -22.3 & 1.8 & 7.0 & 1.8 \\
\hline Whelk & 5 & -21.1 & 2.3 & 5.8 & 1.1 \\
\hline
\end{tabular}

\section{Macrofauna}

The largest number of macrobenthic species was found in the Phoenix vent (ASHES vent field) sample (Table 1). At Phoenix, 8 macrofaunal species were identified, compared to 4 species each at Tubeworm, Village and Marker N3. Three species, the gastropods Lepetodrilus fucensis and Depressigyra globulus and the polychaete Amphisamytha galapagensis, co-occurred at all sites. Adult $L$. fucensis limpets were only recorded at the Phoenix vent though juveniles of the same species outnumbered them at this site. Gut contents of polynoid polychaetes found in the Phoenix sample contained up to 7 intact (juvenile) Lepetodrilus shells.

\section{Meiofauna}

The harpacticoid copepod Amphiascus sp. was the most numerically dominant organism in all of the blue mat samples and occurred at all sites (Table 1). It belongs to the 'minutus' group and most resembles A. longarticulatus Marcus. The blue mat-associated Amphiascus copepod is likely new to science (Michel Clément pers. comm.). Other unidentified copepods (ca. 4 or 5 types) were also present, although not nearly as abundant. The nematodes Chromadoridae and Geomonhystera sp. cooccurred at all sites, except the Village vent (Axial Volcano). Geomonhystera sp. were more abundant than Chromadoridae in all but one sample. The only other meiofaunal organism to be present at all sites (though in small numbers) was the ostracod Podocopida sp.

\section{Stable isotope analyses}

Stable carbon and nitrogen isotope values for individuals of the same species varied between sites and between samples (Table 2). Folliculinopsis sp. ciliates were the most depleted in $\delta^{13} \mathrm{C}$ (average values between sites ranged from -30 to $-35 \%$ ) of all species analyzed. 
Table 3. Fatty acid composition for Folliculinopsis sp., samples R682-0005 and R682-0006, from Clam Bed, Main Endeavor vent field, Juan de Fuca Ridge. SFA: saturated fatty acids; MUFA: monounsaturated fatty acids; PUFA: polyunsaturated fatty acids (3 or more double bonds); OBFA: odd and/or branched fatty acids; NMID: non-methylene-interrupted dienes; BACT: bacterial markers, i.e. $\Sigma$ OBFA $+\omega 4$ dienes + $16: 1 \omega 7+18: 1 \omega 7$

\begin{tabular}{|c|c|c|}
\hline \multirow[t]{2}{*}{ Fatty acid } & \multicolumn{2}{|c|}{ Folliculinopsis sp. } \\
\hline & R682-0005 (\%) & R682-0006 (\%) \\
\hline \multicolumn{3}{|l|}{ SFA } \\
\hline $14: 0$ & 2.04 & 1.96 \\
\hline $\mathrm{i}-15: 0$ & 0.51 & 0.65 \\
\hline ai-15:0 & 0.5 & 1.3 \\
\hline 15:0 & 0.72 & 0.79 \\
\hline i-16:0 & 0.26 & 0.25 \\
\hline $16: 0$ & 11.36 & 15.31 \\
\hline $\mathrm{i}-17: 0$ & 0.38 & 0.36 \\
\hline $17: 0$ & 0.72 & 0.61 \\
\hline $18: 0$ & 2.74 & 2.91 \\
\hline $20: 0$ & & 0.25 \\
\hline \multicolumn{3}{|l|}{ MUFA } \\
\hline $14: 1$ & 1.05 & 1.05 \\
\hline $16: 1 \omega 7$ & 30.47 & 29.5 \\
\hline $18: 1 \omega 9+\omega 13$ & 3.39 & 5.06 \\
\hline $18: 1 \omega 7$ & 33.2 & 24.06 \\
\hline $20: 1 \omega 13+\omega 9$ & 1.78 & 2.2 \\
\hline $20: 1 \omega 7$ & 2.46 & 2.49 \\
\hline \multicolumn{3}{|l|}{ PUFA } \\
\hline $20: 4 \omega 6$ & & 0.33 \\
\hline $20: 5 \omega 3$ & 1.05 & 0.69 \\
\hline \multicolumn{3}{|l|}{ Dienes } \\
\hline $18: 2 \omega 6$ & 1.28 & 2.01 \\
\hline $18: 2 \omega 4$ & 4.17 & 5.6 \\
\hline 20:2D5,11 & & 0.23 \\
\hline $20: 2 \mathrm{D} 5,13$ & & 0.28 \\
\hline 20:2D13,16 & 0.99 & 1.07 \\
\hline $22: 2 \mathrm{D} 7,15$ & 0.92 & 1.03 \\
\hline \multicolumn{3}{|l|}{ Group totals } \\
\hline SFA & 19.23 & 24.39 \\
\hline MUFA & 72.35 & 64.36 \\
\hline Dienes & 7.37 & 10.22 \\
\hline PUFA & 1.05 & 1.02 \\
\hline OBFA & 3.09 & 3.96 \\
\hline NMID & 1.91 & 2.61 \\
\hline \multicolumn{3}{|c|}{ Feeding indices } \\
\hline PUFA/SFA & 0.05 & 0.04 \\
\hline $16: 1 \omega 7 / 16: 0$ & 2.68 & 1.93 \\
\hline $18: 1 \omega 7 / 18: 0$ & 12.14 & 8.27 \\
\hline $18: 1 \omega 9 / \omega 7$ & 0.1 & 0.21 \\
\hline$\omega 4$ dienes & 4.17 & 5.6 \\
\hline $\mathrm{BACT}$ & 70.94 & 63.12 \\
\hline BACT/PUFA & 67.28 & 61.6 \\
\hline PUFA/BACT & 0.01 & 0.02 \\
\hline
\end{tabular}

At Phoenix, $\delta^{15} \mathrm{~N}$ values indicated that juvenile (mean shell length $=0.6 \mathrm{~mm}$ ) and adult (mean shell length $=10.1 \mathrm{~mm}$ ) Lepetodrilus fucensis occupied different trophic levels. The juvenile limpets had a mean $\delta^{15} \mathrm{~N}$ of $4.5 \%$, while, for adult limpets, the mean $\delta^{15} \mathrm{~N}$ was 7.5\% (see Fry 2006 for an explanation of inferences of trophic level differences based on stable nitrogen isotope values). The juvenile limpets at Phoenix were more depleted in both ${ }^{15} \mathrm{~N}$ and ${ }^{13} \mathrm{C}$ than the adults. The latter's carbon and nitrogen stable isotope ratios tended to group with those of other macrofauna, such as the gastropod Depressigyra globulus, pycnogonids and an unidentified whelk. At all sites, except Marker N3, juvenile L. fucensis $\delta^{15} \mathrm{~N}$ and $\delta^{13} \mathrm{C}$ values were similar to those of the copepod Amphiascus sp. The species with the greatest between-site variation in $\delta^{15} \mathrm{~N}$ and $\delta^{13} \mathrm{C}$ was the polychaete Amphisamytha galapagensis, ranging from 4.9 to $8.2 \%$ for $\delta^{15} \mathrm{~N}$ and from -24 to $-29 \%$ for $\delta^{13} \mathrm{C}$.

The numerically dominant copepod Amphiascus sp. had mean $\delta^{13} \mathrm{C}$ values that ranged from -23 to $-27 \%$ and mean $\delta^{15} \mathrm{~N}$ values that ranged from 4 to $6 \%$ between sample sites. Individuals of the same species of unidentified copepods were too few in number to provide enough pooled biomass for stable isotope analyses. The 2 nematode species found within blue mat samples were only abundant enough at Tubeworm and Marker N3 for isotope analyses. Chromadoridae appear to occupy a higher trophic level, with $\delta^{15} \mathrm{~N}$ for pooled specimens ranging from 5.2 to $7.4 \%$. For the single pooled sample of Geomonhystera sp. (at Tubeworm) $\delta^{15} \mathrm{~N}$ was $4.8 \%$. The $\delta^{13} \mathrm{C}$ values for nematodes from pooled specimens from the 2 Tubeworm vent samples ranged from -23.5 to $-24.8 \%$.

A comparison of carbon and nitrogen isotopic signatures of metazoans found within the blue mats to values for the same species collected from other vent habitats on Axial Volcano indicates that there are significant differences between the carbon isotopic values of, for example, Lepetodrilus fucensis ( $t$-test, $\mathrm{p}<0.001$ ) and Amphisamytha galapagensis (t-test, p < 0.001) within and outside of the folliculinid colonies (Fig. 1). Average A. galapagensis $\delta^{13} \mathrm{C}$ values were $-26.9 \%$ at blue mat sites and $-17.9 \%$ in other vent habitats, while average $L$. fucensis $\delta^{13} \mathrm{C}$ values were $-22.4 \%$ at blue mat sites and $-15.7 \%$ in other vent habitats (see Levesque et al. 2006 for average isotope values outside of the blue mat).

\section{Lipid composition}

The blue mat fatty acids were predominantly saturated and monounsaturated, and they contained very little PUFA. This is a common bacterial signature and indicates a dominance of bacterial-synthesized lipids in the samples. The lipid analyses also provide evidence of the presence of sulfur-oxidizing bacteria. Sulfur oxidizers are largely composed of 16:1 107 and 

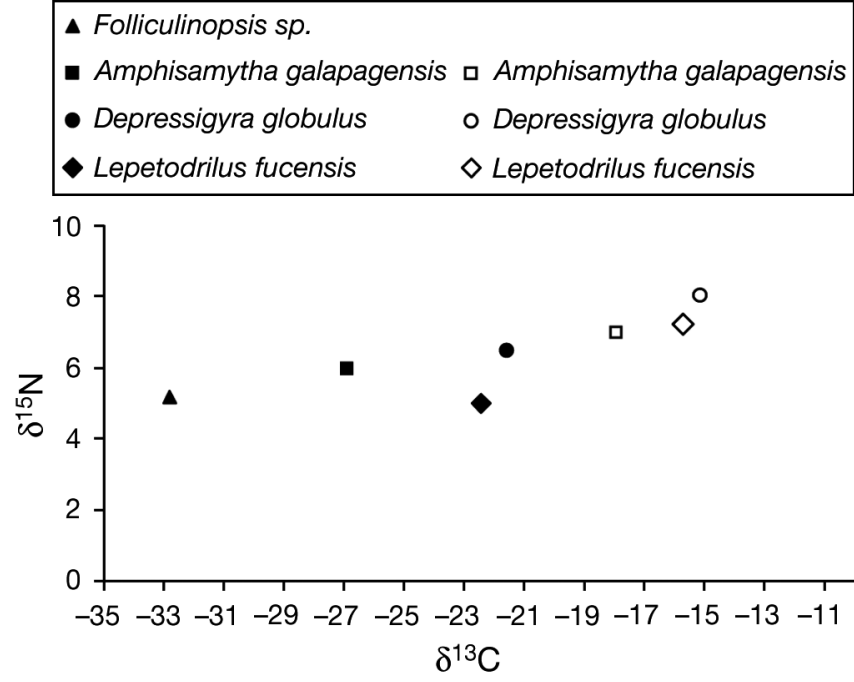

Fig. 1. Comparison of average stable carbon and nitrogen isotope values of the same species at blue mat sites (filled symbols) and at vent sites that are not dominated by blue mats (open symbols) (Levesque et al. 2006) on the 1998 Axial Volcano vent field. ( $t$-test for $\delta^{13} \mathrm{C}$ differences: Amphisamytha galapagensis, $\mathrm{p}<0.001$; Depressigyra globulus, $\mathrm{p}=0.07$; Lepetodrilus fucensis, $\mathrm{p}<0.001$ )

18:107 (Conway \& McDowell Capuzzo 1991), and these make up over half of the fatty acids in blue mats. 18:2 $\omega 4$ is also a bacterial fatty acid (Pond et al. 1997), and the levels are notable in blue mats. The simple fatty acid profiles of the blue mats reflect their chemosynthetic environment. The 2 samples were similar except that the one (R682-0005) had a higher pro-

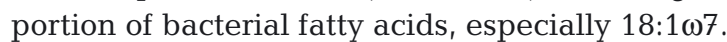

\section{DISCUSSION}

On the periphery of the Juan de Fuca and Explorer Ridge vents sampled in the present study (with the exception of the Phoenix vent), the surface area occupied by blue mat ciliates (visible to the naked eye through observations of video recordings taken by the submersible) by far exceeds the area occupied by any other visible species and is even more impressive if the microscopic size of these ciliates is taken into account. The distribution of the folliculinid ciliates on diffuseflow basalt-hosted vents in the NE Pacific resembles that of the Bathymodiolin mussel communities from the Galapagos Spreading Center as described by Johnson et al. (1994): shimmering hydrothermal effluents escaping from cracks in the basalt are closely surrounded by erect vestimentiferan worms whose bright red plumes are visible. Stacked limpets and white bacterial mats immediately surround many NE Pacific vestimentiferan aggregations. The blue mats then circum- scribe the stacked limpets, bacterial mats and tubeworms. The Phoenix vent was the only sulfide edifice site sampled in this study. There, blue mats formed patches on the sulfide mineral edifice.

Our observation that juvenile Lepetodrilus fucensis limpets are more abundant than adult limpets within blue mat sites agrees with the findings of Bates (2008) that recruit-sized and juvenile limpets occupy areas of peripheral vent flow, while adult limpets occupy areas closer to intense flow. Bates (2008) showed that limpets move inward towards high-flow areas as they grow, such that size partitioning occurs along a hydrothermal gradient (limpet size increases with proximity to active flow). Since juvenile $L$. fucensis are present in all blue mat samples and since there is a continuity of habitat between the blue mats and other habitats, it is reasonable to suggest that these limpets may use the folliculinid colonies as a nursery. They may thus pass through their juvenile phase in the blue mats and eventually migrate along a hydrothermal gradient towards more intensive hydrothermal flow.

\section{Faunal composition}

Macrofaunal species such as Amphisamytha galapagensis, Lepetodrilus fucensis and Depressigyra globulus are not exclusively associated with our collected blue mat samples but rather are a recurrent component of the NE Pacific hydrothermal vent fauna. On the other hand, meiofaunal species such as the numerically dominant harpacticoid copepod Amphiascus sp. and the nematodes Chromadoridae and Geomonhystera sp. have not previously been reported from the Juan de Fuca or Explorer Ridges and are found in almost all of the blue mat samples collected for the present study. Harpacticoid copepods are common at vents (Huys \& Conroy-Dalton 1997, Lee \& Huys 2000, Willen 2003, Gollner et al. 2006, Gomez \& Boyko 2006), although Amphiascus sp. has previously only been reported from shallow (90 m) sub-polar Mid-Atlantic Ridge vents (Fricke et al. 1989).

Aggregations of vestimentiferan tubeworms (Riftia pachyptila) from the East Pacific Rise (EPR) host permanent benthic communities, one-third of the total species richness of which is comprised of meiobenthic fauna (Gollner et al. 2007). Nematodes and copepods were the 2 most abundant meiobenthic taxa within both mussel beds and vestimentiferan bushes on the EPR (Zekely 2006a, Gollner et al. 2007). Faunal abundance in colonies of blue mats sampled from the Explorer and the Juan de Fuca Ridges was dominated by meiobenthic species. There was also a greater number of meiobenthic species compared to macrobenthic 
species in all samples, except those from the Phoenix vent. Macrofauna, such as adult limpets, pycnogonids and polynoid polychaetes, found at Phoenix, but not at other blue mat sites, are likely transients from adjacent surfaces on the same sulfide edifice structure, which is colonized by a typical example of the macrofaunal mosaic described by Sarrazin \& Juniper (1999).

Meiofaunal species composition at vents differs from adjacent, non-vent, soft-bottom areas of the deep sea (Dinet et al. 1988, Tsurumi et al. 2003). Dinet et al. (1988) found that overall meiofaunal abundance and species diversity did not vary greatly between samples collected from vents on the EPR and the Explorer Ridge. Species composition within vent fields, however, does differ. For example, the dominant copepod species found in habitats close to vents on the Juan de Fuca Ridge is Stygiopontius quadrispinosus, whereas Aphotopontius forcipatus was the most abundant copepod at new vents, and Benthoxynus spiculifer, at old vents (all three are siphonostomatoid copepod species) (Tsurumi et al. 2003). In the present study we found considerable variation in community composition in terms of both relative abundance and presence and absence of species, including at Magic Mountain, where replicate sampling was possible. Nevertheless, a distinct meiobenthic community within the blue mats composed of species not recorded from adjacent highflow vent sites was observed. Habitat-specific meiofaunal assemblages have also been observed at EPR vents. Meiobenthos associated with detrital material sampled from the base of the vents differed from those associated with megafauna, such as the polychaete Alvinella pompejana, the vesicomyid clam Calyptogena magnifica clams and the giant tubeworm Riftia pachyptila (Dinet et al. 1988). At the $21^{\circ} \mathrm{N}$ vent field on the EPR, nematode species composition differed between hydrothermal vents, as well as from surrounding oxic environments, cold seeps and subsurface anoxic sediments (Vanreusel et al. 1997).

\section{Food web structure}

A notable range of stable isotope values was observed for blue mat ciliate samples (from -35 to $-30 \%$ o) between locations. Further, within a single vent site, we can see variations of up to $3 \%$ for species sampled on separate dives at the same general location. Small-scale spatial variability in food source carbon isotope signatures appears to be ultimately related to local exposure to hydrothermal discharge as well as fluid physico-chemical properties. These habitat properties can shape vent food webs and influence the spatial distribution of primary producer organisms and the meiobenthos (Limén et al. 2007). In our samples, there appear to be 2 end-member stable carbon isotope signatures (-12 and $-30 \%$ ) that are the result of $2 \mathrm{CO}_{2}$ fixation pathways, as is frequently observed at vents. One pathway appears to be distinct to the blue mat (35 to $-30 \%$ ), while the other characterizes particulate organic matter from other sources (e.g. free-living filamentous bacteria).

The blue mat ciliates have previously been suggested to serve as a food source for other species. Folliculinids have been found in digestive tracts of galatheid crabs (Small \& Gross 1985). Based on similar isotopic signatures, as well as observations of mouthparts and gut content, Bergquist et al. (2007) suggested that the gastropod Clypeosectus curvus, associated with tubeworm bushes on the Juan de Fuca Ridge, is a specialized consumer of folliculinid ciliates. This gastropod was not found within the 5 blue mat samples analyzed in the present study, and our stable isotopic analyses do not reveal any potentially exclusive consumer of vent folliculinids within the blue mat assemblages. However, our comparison of average stable carbon and nitrogen values does show that metazoans associated with the blue mat are more depleted in carbon than they are outside of the blue mat areas. Thus, these metazoans appear to be deriving at least part of their nutrition from organic matter produced by the folliculinids (either through direct predation on the ciliates or through feeding on detrital mat material). This is supported by our microscopic observations of bluish pigmentation in the tissues of all sampled mat invertebrates. The blue mat fauna may also feed on allochthonous organic matter, of hydrothermal (chemosynthetic) and photosynthetic origin that accumulates within the matrix of the mats.

There is evidence that some members of the blue mat fauna feed at different trophic levels. Based on gut content analyses, polynoid polychaetes appear to prey upon juvenile limpets at the Phoenix vent. For the polychaete Amphisamytha galapagensis, mean $\delta^{13} \mathrm{C}$ values for specimens from a single sample varied the most between samples and sites, suggesting that this potential mobile predator has a more generalized opportunistic diet. Adult Lepetodrilus fucensis limpets at the Phoenix vent have a less blue mat-influenced, depleted carbon isotope signature than juveniles from the same site and may be opportunistic feeders, possibly transient in the mat.

Stable isotopic signatures also indicate at least 2 trophic levels within the meiobenthic assemblage: the nematode Chromadoridae could be feeding on detritus including decaying body parts of, for example, the abundant copepod Amphiascus sp. (unlikely to catch live copepods). Abundant Amphiascus sp. in blue mats are likely to generate a detrital pool composed of 
decaying body parts, which could serve as a food source to detritus/omnivorous invertebrates. Siphonostomatoid copepods at vents have previously been suggested to be consumed along with other particulate debris, in that case by paralvinellid worms (Limén et al. 2008). Another meiobenthic species potentially feeding on the numerically dominant Amphiascus sp. is the ostracod Euphilomedes climax. At Juan de Fuca Ridge vents, E. climax has been shown to be enriched in $\delta^{15} \mathrm{~N}$ (Limén et al. 2007), indicating a predatory feeding mode. Most members of its family (Philomedidae) are detritus feeders, but examination of E. climax gut contents in other habitats has shown that it may also ingest small invertebrates such as copepods (Kornicker 1991). Finally, it is possible that metazoans associated with blue mat assemblages derive nutrition from the episymbiotic microorganisms hosted by these folliculinid ciliates. A recent study (Kouris et al. unpubl. data) reported the presence of epsilon- and alpha-Proteobacteria on the surface of the ciliate lorica. Using 16S rRNA sequence analysis and confirmed by fluorescent in situ hybridization, these authors found that the epsilon-Proteobacteria were closely related to known sulfur-oxidizing Rimicaris exoculata ectosymbionts (Kouris et al. unpubl. data). Based on this and on our lipid data, carbon fixed through the oxidation of reduced sulfur species appears to form the base of the blue mat food webs.

\section{CONCLUSIONS}

With the exception of studies that consider new vent colonization, spatial and temporal dynamics of vent faunal communities still remain poorly understood. Several lines of evidence presented here suggest that blue mats host a recurrent and interacting community of invertebrates. The 3 major macrofaunal species, known from other vent habitats, were present at all locations. At least 3 previously unreported meiofaunal species were found in our mat samples, one of which (Amphiascus sp.) was the most abundant metazoan in all collections. Stable isotope and gut content analyses and microscopic examination of faunal tissues indicate that the macroinvertebrates were at least partially feeding on blue mat ciliates. Lipid analysis of mat material and a previous ultrastructure study suggest that sulfide-oxidizing autotrophic symbionts are the primary source of carbon for the mats and their associated food webs. These mats occupy significant areas of substratum at peripheral and lowflow hydrothermal areas of the NE Pacific. This provides supplementary habitat (and food) for vent macroinvertebrates, and may represent the only habitat for 3 meiofaunal species.
Acknowledgements. This work was financially supported by a doctoral fellowship from GEOTOP research center (A.K.) and research grants to S.K.J. from the Natural Sciences and Engineering Research Council of Canada (NSERC). The authors thank the crews of the RV Thomas G. Thompson and the ROPOS submersible for their collaboration at sea, as well as M. Clément for taxonomic assistance (copepods), R. Dancette for assistance in sample preparation (lipid) and A. Ouellet for developing the GC column program. This study was performed in Canada and is in compliance with current laws.

\section{LITERATURE CITED}

Ackman R (1986) WCOT (capillary) gas-liquid chromatography. In: Hamilton R, Rossell J (eds) Analysis of oils and fats. Elsevier, London, p 137-206

Bates A (2008) Size- and sex-based habitat partitioning by Lepetodrilus fucensis near hydrothermal vents on the Juan de Fuca Ridge, Northeast Pacific. Can J Fish Aquat Sci 65:2332-2341

> Bergquist DC, Eckner JT, Urcuyo IA, Cordes EE, Hourdez S, Macko SA, Fisher CR (2007) Using stable isotopes and quantitative community characteristics to determine a local hydrothermal vent food web. Mar Ecol Prog Ser 330: 49-65

Bergquist DC, Ward T, Cordes EE, McNelis T and others (2003) Community structure of vestimentiferan-generated habitat islands from Gulf of Mexico cold seeps. J Exp Mar Biol Ecol 289:197-222

Calbet A, Saiz E (2005) The ciliate-copepod link in marine ecosystems. Aquat Microb Ecol 38:157-167

> Conway N, McDowell Capuzzo J (1991) Incorporation and utilization of bacterial lipids in the Solemya velum symbiosis. Mar Biol 108:277-291

Dinet A, Grassle F, Tunnicliffe V (1988) Premières observations sur la méiofaune des sites hydrothermaux de la dor-

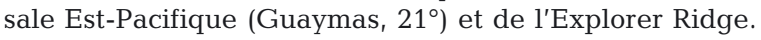
Oceanol Acta Spec Vol:7-14

Embley RW, Chadwick WW Jr, Clague D, Stakes D (1999) 1998 eruption of Axial Volcano: multibeam anomalies and sea-floor observations. Geophys Res Lett 26: 3425-3428

Epstein SE, Gallagher D (1992) Evidence for facilitation and inhibition of ciliate population growth by meiofauna and macrofauna in a temperate zone sandflat. J Exp Mar Biol Ecol 155:27-39

Fricke H, Giere O, Stetter K, Alfredsson GA, Kristjansson JK, Stoffers P, Svavarsson J (1989) Hydrothermal vent communities at the shallow subpolar Mid-Atlantic Ridge. Mar Biol 102:425-429

Fry B (2006) Stable isotope ecology. Springer Science + Business Media, New York, NY

Gomez S, Boyko CB (2006) On a small collection of harpacticoids from Easter Island: the family Laophontidae T. Scott (Crustacea: Copepoda: Harpacticoida). Zootaxa 1352: $1-70$

Gollner S, Zekely J, Van Dover CL, Govenar B, Le Bris N, Nemeschkal HL, Bright M (2006) Benthic copepod communities associated with tubeworm and mussel aggregations on the East Pacific Rise. Cah Biol Mar 47:397-402

Gollner S, Zekely J, Govenar B, Le Bris N, Nemeschkal HL, Fisher CR, Bright M (2007) Tubeworm-associated permanent meiobenthic communities from two chemically different hydrothermal vent sites on the East Pacific Rise. Mar Ecol Prog Ser 337:39-49 
Hamels I, Moens T, Muylaert K, Vyverman W (2001) Trophic interactions between ciliates and nematodes from an intertidal flat. Aquat Microb Ecol 26:61-72

Huys R, Conroy-Dalton S (1997) Discovery of hydrothermal vent Tantulocarida on a new genus of Argestidae (Copepoda: Harpacticoida). Cah Biol Mar 38:235-249

- Johnson KS, Childress JJ, Beehler CL, Sakamoto CM (1994) Biogeochemistry of hydrothermal vent mussel communities: the deep-sea analogue to the intertidal zone. DeepSea Res I 41:993-1011

Kornicker L (1991) Myodocopid Ostracoda of hydrothermal vents in the eastern Pacific Ocean. Smithson Contrib Zool 516:1-46

Kouris A, Juniper SK, Frebourg G, Gaill F (2007) Protozoanbacterial symbiosis in a deep-sea hydrothermal vent folliculinid ciliate (Folliculinopsis sp.) from the Juan de Fuca Ridge. PSZN I: Mar Ecol 28:63-71

Lee W, Huys R (2000) New Aegisthidae (Copepoda: Harpacticoida) from western Pacific cold seeps and hydrothermal vents. Zool J Linn Soc 129:1-71

> Levesque C, Juniper SK, Marcus J (2003) Food resources partitioning and competition among alvinellid polychaetes of Juan de Fuca Ridge hydrothermal vents. Mar Ecol Prog Ser 246:173-182

> Levesque C, Juniper SK, Limén H (2006) Spatial organization of food webs along habitat gradients at deep-sea hydrothermal vents on Axial Volcano, Northeast Pacific. Deep-Sea Res I 53:726-739

Limén H, Juniper SK (2006) Habitat controls on vent food webs at Eifuku Volcano, Mariana Arc. Cah Biol Mar 47: $449-455$

Limén H, Juniper SK, Tunnicliffe V, Clément M (2006) Benthic community structure on two peaks of an erupting seamount: Northwest Rota-1 Volcano, Mariana Arc, western Pacific. Cah Biol Mar 47:457-463

Limén H, Levesque C, Juniper SK (2007) POM in macro/meiofaunal food webs associated with three flow regimes at deep-sea hydrothermal vents on Axial Volcano, Juan de Fuca Ridge. Mar Biol 153:129-139

Limén H, Stevens CJ, Bourass Z, Juniper SK (2008) Trophic ecology of siphonostomatoid copepods at deep-sea hydrothermal vents in the northeast Pacific. Mar Ecol Prog Ser 359:161-170

Parrish C (1999) Determination of total lipid, lipid classes, and fatty acids in aquatic samples. In: Arts M, Wainman B (eds) Lipids in freshwater ecosystems. Springer-Verlag, New York, NY, p 4-20

Pond DW, Dixon DR, Bell MV, Fallick AE, Sargent JR (1997) Occurrence of 16:2 (n-4) and 18:2 (n-4) fatty acids in the lipids of the hydrothermal vent shrimps Rimicaris exoculata and Alvinocaris markensis: nutritional and trophic implications. Mar Ecol Prog Ser 156:167-174

Editorial responsibility: Hans Heinrich Janssen, Oldendorf/Luhe, Germany
Reiss J, Schmid-Araya JM (2008) Existing in plenty: abundance, biomass and diversity of ciliates and meiofauna in small streams. Freshw Biol 53:652-668

Sarrazin J, Juniper SK (1999) Biological characteristics of a hydrothermal edifice mosaic community. Mar Ecol Prog Ser 185:1-19

Small EB, Gross ME (1985) Preliminary observations of protistan organisms, especially ciliates from the $21^{\circ} \mathrm{N}$ hydrothermal vent site. Biol Soc Wash Bull 6:401-410

Stevens C, Limén H, Pond D, Gélinas Y, Juniper SK (2008) Ontogenetic shifts in the trophic ecology of two alvinocaridid shrimp species at hydrothermal vents on the Mariana Arc, western Pacific Ocean. Mar Ecol Prog Ser 356:225-237

Tsurumi M, De Graaf RC, Tunnicliffe V (2003) Distributional and biological aspects of copepods at hydrothermal vents on the Juan de Fuca Ridge, north-east Pacific Ocean. J Mar Biol Assoc UK 83:469-477

Tsurumi M, Tunnicliffe V (2001) Characteristics of a hydrothermal vent assemblage on a volcanically active segment of Juan de Fuca Ridge, northeast Pacific. Can J Fish Aquat Sci 58:530-542

Tunnicliffe V (1988) Biogeography and evolution of hydrothermal-vent fauna in the eastern Pacific Ocean. Proc R Soc Lond B Biol Sci 233:347-366

Tunnicliffe V, Juniper SK, De Burgh ME (1985) The hydrothermal vent community in Axial Seamount, Juan de Fuca Ridge. Biol Soc Wash Bull 6:434-464

Tunnicliffe V, Juniper SK, Sibuet M (2003) Reducing environments of the deep-sea floor. In: Tyler PA (ed) Ecosystems of the world: the deep sea. Elsevier Press, Amsterdam p 81-110

Van Dover CL (1995) Ecology of Mid-Atlantic Ridge hydrothermal vents. In: Parson LM, Walker CL, Dixon DR (eds) Hydrothermal vents and processes. Geological Society, London, No. 87, p 257-294

> Vanreusel A, Van den Bossche I, Thiermann F (1997) Freeliving marine nematodes from hydrothermal sediments: similarities with communities from diverse reduced habitats. Mar Ecol Prog Ser 157:207-219

Willen E (2003) A new species of Stenhelia (Copepoda, Harpacticoida) from a hydrothermal, active, submarine volcano in the New Ireland Fore-Arc system (Papua New Guinea) with notes on deep sea colonization within the Stenheliinae. J Nat Hist 37:1691-1711

Zekely J, Gollner S, Van Dover CL, Govenar B, Le Bris N, Nemeschkal HL, Bright M (2006a) Nematode communities associated with tubeworm and mussel aggregations on the East Pacific Rise. Cah Biol Mar 47:477-482

Zekely J, Van Dover CL, Nemeschkal HL, Bright M (2006b) Hydrothermal vent meibenthos associated with mytilid mussel aggragtions from Mid-Atlantic Ridge and the East Pacific Rise. Deep-Sea Res I 53:1363-1378

Submitted: May 22, 2009; Accepted: May 26, 2010

Proofs received from author(s): August 4, 2010 